\title{
Potential Effects of Management Practices on Nitrogen Nutrition and Long-term Productivity of Western Hemlock Stands
}

\author{
D. SACHS and P. SOLLINS
}

Department of Forest Science, College of Forestry, Oregon State University, Corvallis, OR 97331 (U.S.A.)

(Accepted 18 March 1986)

\begin{abstract}
Sachs, D. and Sollins, P., 1986. Potential effects of management practices on nitrogen nutrition and long-term productivity of western hemlock stands. For. Ecol. Manage., 17: 25-36.

The FORCYTE-10 computer model, developed by J.P. Kimmins and K. Scoullar for Douglasfir forests in British Columbia, was modified to simulate growth and nutrient cycling of coastal western hemlock stands. Initial calibration indicated that predicted yield was extremely sensitive to the rate of mineralization of soil organic matter (SOM), variation in SOM C:N ratio with site quality, the soil extractable $\mathrm{NO}_{3}{ }^{-}: \mathrm{NH}_{4}{ }^{+}$ratio, and the decomposition rate and $\mathrm{N}$ mineralization pattern of large and medium-size roots and woody debris. The predictions suggested that yield and SOM remain stable under a management system consisting of six successive 90 -year rotations. More intensive utilization (e.g., shorter rotations, whole-tree harvesting and commercial thinning) causes depletion of soil and forest floor nitrogen and a small decline in site productivity in later rotations.
\end{abstract}

\section{INTRODUCTION}

To estimate the long-term effects of forest management practices without monitoring yield over several centuries, a method is needed to integrate and project forward the results of current studies. Simulation modeling may help accomplish this objective. A management-oriented model can suggest to land managers the probable long-term consequences of various silvicultural practices and provide researchers with a way to integrate and test ideas. Once critical processes are identified through sensitivity analysis, research can be directed where the need is greatest.

In this study, we worked with FORCYTE-10, a management-oriented simulation model of growth and nutrient cycling for even-aged forests that is widely used in the Pacific Northwest (Kimmins and Scoullar, 1979, 1981, 1982). We 
adapted FORCYTE-10 for western hemlock with data from sites in coastal Oregon and then projected how various silvicultural practices might influence long-term productivity.

\section{DESCRIPTION OF FORCYTE-10}

The FORCYTE-10 model simulates how forest management practices affect the growth of even-aged forests (Kimmins and Scoullar, 1979, 1981, 1982). Growth of stemwood in the model is driven by volume/age equations of the Chapman-Richards type (Pienaar and Turnbull, 1973) for each of five site qualities. Ideally, equation parameters are developed from yield tables for unmanaged stands within one locale. Growth of other tree components is then calculated from a set of age-specific ratios of stem-wood biomass to foliage, branch, stem-bark or root biomass. Information on nitrogen content of each of the tree components is required for each site quality.

Annual nitrogen demand is calculated as a sum of the products of predicted growth of the tree components and their $\mathrm{N}$ contents. If $\mathrm{N}$ demand exceeds availability in any year, growth during that year is reduced to a level at which the available $\mathrm{N}$ supply is fully utilized. If $\mathrm{N}$ availability exceeds normal demand, growth increases, within user-specified limits.

Site quality changes throughout the simulation, depending on the relation between the amount of available $\mathrm{N}$ and tree requirements, which allows growth and decomposition rates to also change. Site quality is reduced when $\mathrm{N}$ demand cannot be satisfied, resulting in decreased growth and $\mathrm{N}$ demand the following year. Conversely, site quality is increased when $\mathrm{N}$ is in excess, the result being increased growth and $\mathrm{N}$ demand the following year.

The biomass and $\mathrm{N}$ content of all decomposing tree and understory components are accounted for separately. Each type of material begins with a specified $\mathrm{N}$ content and decomposes for a specified number of years after which the remaining material becomes soil organic matter (SOM). The SOM includes the forest floor $\mathrm{O}_{2}$ layer. The $\mathrm{N}$ content of each decomposing material approaches that of SOM as it decays. Decomposition rates can vary with both the age of material and site quality, with more rapid rates associated with the better sites. The $\mathrm{N}$ content and decay rate of SOM can also vary with site quality.

\section{CALIBRATION FOR WESTERN HEMLOCK}

\section{Data sources}

Information on stem-wood growth, taken from western hemlock yield tables (Barnes, 1962; Wiley, 1978), was used to construct Chapman-Richards growth equations for site classes I through $\mathrm{V}$. Information on forest floor biomass and 
TABLE 1

Sources for data used in calibration of the model

\begin{tabular}{|c|c|}
\hline Data & Source \\
\hline \multicolumn{2}{|l|}{ Biomass by tree component } \\
\hline 25-year-old stand ( site II) & Fujimori, 1971 \\
\hline 52 -year-old stand ( site III) & Sachs, 1983 \\
\hline 121-year-old stand ( site III) & Grier, 1976 \\
\hline $\begin{array}{l}\text { N. content by component ( sites II, } \\
\text { III) }\end{array}$ & Sachs, 1983; Grier, 1976 \\
\hline $\begin{array}{l}\text { Forest floor biomass and N content, } \\
\text { soil N content ( sites II, } \\
\text { III) }\end{array}$ & $\begin{array}{l}\text { Sachs, 1983, Grier, 1976, } \\
\text { Vitousek et al., 1982, } \\
\text { J.R. Boyle (unpublished) }\end{array}$ \\
\hline Foliar N content ( sites I-IV) & Radwan and DeBell, 1980 \\
\hline $\begin{array}{l}\text { Forest floor biomass and N content, } \\
\text { soil N content ( sites I-IV) }\end{array}$ & Radwan and Shumway, 1983 \\
\hline $\begin{array}{l}\text { N. content by component (low site } \\
\text { Oregon Cascade western hemlock) }\end{array}$ & C.C. Grier (unpublished) \\
\hline $\begin{array}{l}\text { Large woody debris (northwest } \\
\text { coniferous forests) }\end{array}$ & $\begin{array}{l}\text { Sollins, 1982; Graham } \\
\text { and Cromack, } 1982\end{array}$ \\
\hline $\begin{array}{l}\text { Fine root turnover (Douglas-fir } \\
\text { sites II, III) }\end{array}$ & Santantiono and Hermann, 1985 \\
\hline Coarse root decomposition & $\begin{array}{l}\text { S. Cline and P. Sollins } \\
\text { (unpublished) }\end{array}$ \\
\hline Needle decomposition & Edmonds, 1980 \\
\hline
\end{tabular}

$\mathrm{N}$ content, total soil $\mathrm{N}$, and foliar $\mathrm{N}$ content was available for hemlock stands on site I-IV lands; stand biomass by tree component was only available for site II and III lands (Table 1). These data were used directly to calculate agespecific ratios of foliage, branch, bark, and root biomass to stem-wood biomass for site II and III lands. The ratios were used unchanged for site I stands, but the root-to-shoot ratio was increased slightly for poorer sites. Foliar N concentration was set to vary in relation to site quality as indicated by the literature (Table 1). Fine root $\mathrm{N}$ concentration was adjusted to vary in proportion to foliar $\mathrm{N}$ concentrations across sites I through V. Nitrogen concentrations in other tree components were set so that variation was about $10 \%$ that of foliage. Decomposition rates for foliage, logs, and large roots were estimated from the available literature and from unpublished data (Table 1); rates for bark and branches were estimated from data for Douglas-fir forests (Fogel and Cromack, 1977).

Before FORCYTE-10 could be run, an initial state file had to be generated defining the biomass in each age class of decomposing material. This was done by running the model without $\mathrm{N}$ feedback constraints assuming that the growth of a hemlock forest would follow exactly that given in a yield table. The model was set to simulate a site II stand for two 90-year rotations. At the end of that 
period, the model predicted the following forest floor and dead root biomass: $347 \mathrm{Mg}$ ha ${ }^{-1}$ decomposing stemwood; $26 \mathrm{Mg} \mathrm{ha}^{-1}$ bark; $10 \mathrm{Mg} \mathrm{ha}^{-1}$ foliage; 27 $\mathrm{Mg} \mathrm{ha}^{-1}$ branches; $38 \mathrm{Mg} \mathrm{ha}^{-1}$ roots. This set of forest floor values was used as the starting state for subsequent simulations. The amount of decomposing stem-wood is at the upper end of the range of values reported for Pacific Northwest forests (Sollins, 1982). Grier (1976) reported $34 \mathrm{Mg} \mathrm{ha}^{-1}$ of forest floor biomass, excluding material $>2.0 \mathrm{~cm}$ diameter in a 121-year-old western hemlock stand. Sachs (1983) estimated forest floor biomass (material $<1.0 \mathrm{~cm}$ diameter) of $63 \mathrm{Mg} \mathrm{ha}^{-1}$ in a 52 -year-old hemlock stand. Decomposing woody material smaller than $2.0 \mathrm{~cm}$ diameter is not accounted for separately by FORCYTE-10. However, if it is assumed that only a small proportion of the woody material is actually less than $2.0 \mathrm{~cm}$ in diameter then the model's predictions of forest floor biomass seem reasonable.

\section{Sensitivity analysis}

When information describing an ecosystem component or process was unavailable, we made certain assumptions (detailed below). In each case, the sensitivity of the model to these assumptions was tested. Effects of alternate assumptions are discussed later.

We modified the equation defining the rate of fine root turnover in FORCYTE-10 so that death and replacement of any amount of fine root biomass during a year could be simulated. Santantonio and Hermann (1985) showed that fine roots turn over at rates of $2.8,2.0$, and 1.7 year $^{-1}$ in mature Douglasfir forests on dry, medium, and wet sites in the Oregon Cascades. Lacking data for western hemlock, we set fine root turnover at 2.0 year $^{-1}$. We assumed that fine roots decompose in 3-5 years.

We set the SOM decomposition rate at approximately $0.20-0.40 \times 10^{-2}$ year $^{-1}$, increasing with site quality. Rates above this range resulted in extremely high levels of available soil $\mathrm{N}$ that result in unrealistically high rates of tree growth and nitrate leaching. Conversely, rates lower than this range reduced $\mathrm{N}$ availability so that tree growth was quickly and severely limited.

The amount of leaching was extremely sensitive to the ratio of soil extractable nitrate to ammonia. At the end of each year, $\mathrm{NH}_{4}{ }^{+}$not taken up by vegetation or immobilized during decomposition is assumed to accumulate as soil $\mathrm{N}$; any remaining $\mathrm{NO}_{3}{ }^{-}$leaches from the soil. We initially set the $\mathrm{NO}_{3}{ }^{-}: \mathrm{NH}_{4}{ }^{+}$ ratio to 0.54 as indicated by Vitousek et al. (1982) for extractable inorganic $\mathrm{N}$ in the top $15 \mathrm{~cm}$ of soil of an Oregon coastal hemlock site.

Predicted yield proved extremely sensitive to the variation in carbon:nitrogen ratio of SOM with site quality. We tested two basic assumptions. First we set the C:N ratio of SOM at 10:1 on a good site and $30: 1$ on a poor site. The alternate assumption was that the C:N ratio of SOM was 20:1 across all sites. If the ratio is allowed to vary with site quality in the model, the avail- 


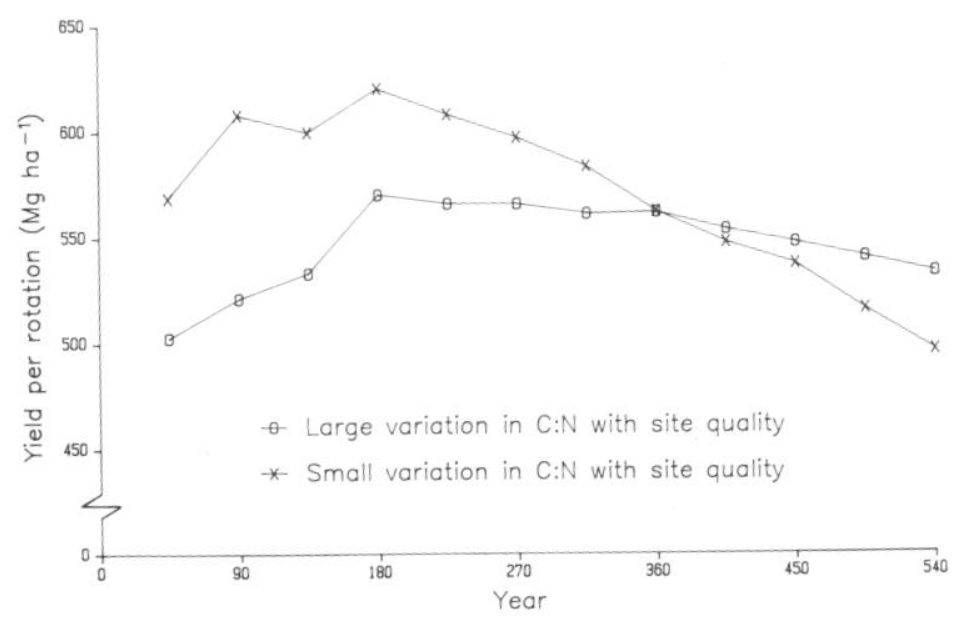

Fig. 1. Effect of variation in soil organic matter C:N ratio with site quality on predicted yield. Management system consisted of 45-year rotations with a precommercial and a commercial thinning.

able $\mathrm{N}$ pool will be buffered. As available $\mathrm{N}$ increases so does site quality. This causes more $\mathrm{N}$ immobilization as forest floor components decompose and must reach a higher final $\mathrm{N}$ content on better sites to become SOM. Increased immobilization by the forest floor results in less available $\mathrm{N}$ for tree growth and, consequently, reduced site quality. This sequence mirrors an active microbial population that increases in biomass as $\mathrm{N}$ availability increases. If, on the other hand, the C:N ratio of SOM remains constant regardless of site quality, increases in available $\mathrm{N}$ do not significantly change the amount of $\mathrm{N}$ immobilized by decomposing material. This results in faster tree growth and higher yields during the first several rotations, but a more rapid depletion of the SOM and eventually a decline in yield (Fig. 1). With the first assumption the model maintained SOM levels stable under a minimum management system for three 90 -year rotations. With the second, less realistic assumption, the model did not maintain stable SOM under any management system.

As each component of the forest floor decomposes, its $\mathrm{N}$ concentration approaches that of SOM. The rate of change in $\mathrm{N}$ concentration over time can follow a number of possible patterns (Fig. 2), the choice of which directly affects net $\mathrm{N}$ mineralization. Predictions of yield are particularly sensitive to changes in the decomposition rate and $\mathrm{N}$ mineralization pattern of materials that decompose slowly because such materials immobilize or mineralize $\mathrm{N}$ for many years. Figure 3 contrasts two alternative assumptions about net mineralization by coarse roots. If coarse roots asymptotically approach the $\mathrm{N}$ concentration of SOM, they immobilize $\mathrm{N}$ early, then mineralize $\mathrm{N}$ during the years of maximum tree demand. If instead an exponential pattern is assumed, much less $\mathrm{N}$ is mineralized during the period of maximum tree demand, and 


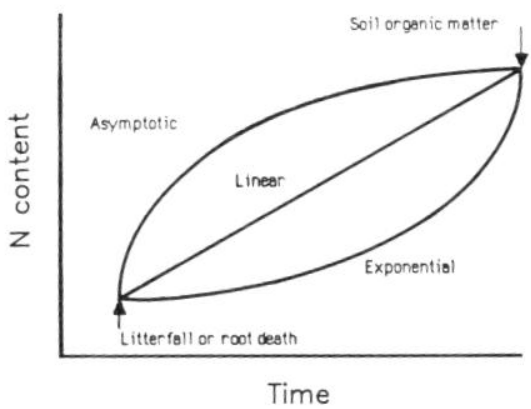

Fig. 2. Alternate patterns of change in nutrient concentration during decomposition (after Kimmins and Scoullar, 1979).

predicted yields are lower. A linear pattern produced intermediate results. Based upon preliminary data for Cascade Range western hemlock (S. Cline and P. Sollins, unpublished), we chose an exponential mineralization pattern for coarse roots.

Lowering the ratio of extractable $\mathrm{NO}_{3}{ }^{-}$to $\mathrm{NH}_{4}{ }^{+}$in the soil from 0.54 to 0.11 significantly increased predicted yields (Fig. 4) and decreased leaching losses (Table 2). Predicted leaching was maximum during the first 15 years following clearcutting. During this period the model predicted that there was little uptake by vegetation and that immobilization by the microflora in the forest floor was a major sink for N. Shorter rotations and intensive utilization increased predicted leaching losses because more frequent disturbance and removal of material prevented immobilization of $\mathrm{N}$ as it was released during decomposition of the forest floor (Table 2). Predicted losses of $\mathrm{NO}_{3}{ }^{-}$are not unreasonable.

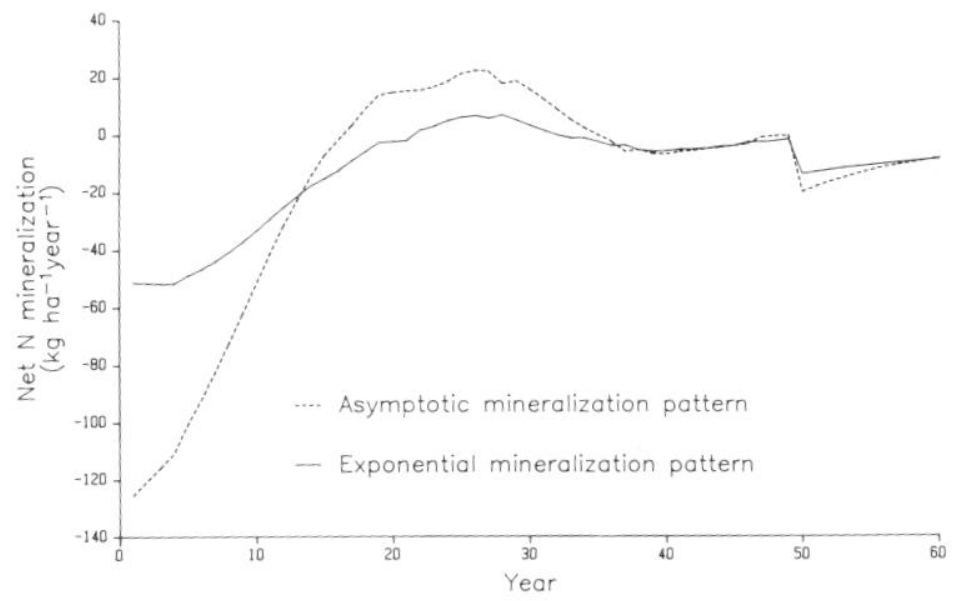

Fig. 3. Projected effect of alternate mineralization patterns on net $\mathrm{N}$ mineralization from decomposing coarse roots. 


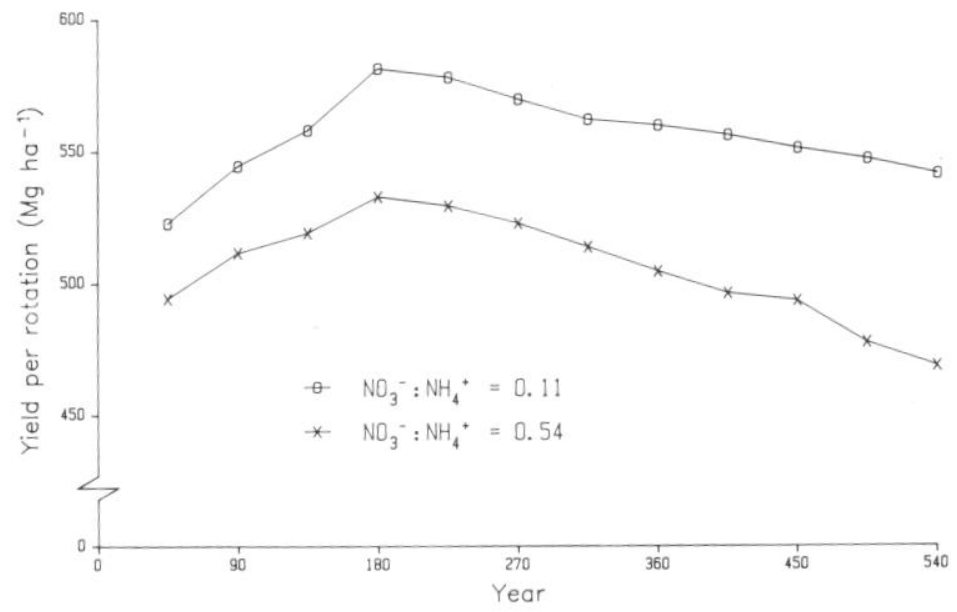

Fig. 4. Projected effect of ratio of soil extractable $\mathrm{NO}_{3}{ }^{-}: \mathrm{NH}_{4}{ }^{+}$on yield. Management system consisted of 45-year rotations with a pre-commercial and a commercial thinning.

Vitousek et al. (1982) reported $\mathrm{NO}_{3}{ }^{-}-\mathrm{N}$ concentrations averaging $>5 \mathrm{ppm}$ beneath trenched plots at a Coastal Oregon site which would translate to a $\mathrm{NO}_{3}{ }^{-}-\mathrm{N}$ loss in excess of $100 \mathrm{~kg} \mathrm{ha}^{-1}$ year $^{-1}$. In addition, FORCYTE-10 does not account for $\mathrm{N}$ lost in a gaseous form through denitrification. We therefore left the ratio of $\mathrm{NO}_{3}{ }^{-}$to $\mathrm{NH}_{4}{ }^{+}$at 0.54 for the management simulations.

Because the rate of SOM decomposition is unmeasured and greatly affects predicted yield, small adjustments in this rate can be used to tune the model. For example, if fine root turnover is changed from 2.0 year $^{-1}$ to 3.0 year $^{-1}$, predicted yield declines about $5 \%$ during each 90 -year rotation of a 270 -year

\section{TABLE 2}

Effect of soil $\mathrm{NO}_{3}{ }^{-}: \mathrm{NH}_{4}{ }^{+}$ratio, rotation length, and utilization level on predicted leaching losses of $\mathrm{NO}_{3}{ }^{-}-\mathrm{N}$ during a 90 year simulation $(\mathrm{PCT}=$ pre-commercial thinning, $\mathrm{CT}=$ commercial thinning)

\begin{tabular}{|c|c|c|c|c|}
\hline \multirow[t]{3}{*}{ Management system } & \multicolumn{4}{|c|}{$\mathrm{NO}_{3}{ }^{-}-\mathrm{N}$ leached $\left(\mathrm{kgha}^{-1}\right.$ year $\left.^{-1}\right)$} \\
\hline & \multicolumn{2}{|c|}{$\mathrm{NO}_{3}{ }^{-}: \mathrm{NH}_{4}{ }^{+}=0.11$} & \multicolumn{2}{|c|}{$\mathrm{NO}_{3}^{-}: \mathrm{NH}_{4}^{+}=0.54$} \\
\hline & average & $\max$ & average & $\max$ \\
\hline $\begin{array}{l}30 \text { year, whole-tree } \\
\text { harvest }\end{array}$ & 10 & 45 & 23 & 135 \\
\hline $\begin{array}{l}45 \text { year, } \mathrm{PCT} \text { at } 15 \text {, } \\
\mathrm{CT} \text { at } 30\end{array}$ & 7 & 43 & 16 & 125 \\
\hline 90 year & 3 & 22 & 7 & 56 \\
\hline
\end{tabular}


period. However, the predicted amount of SOM increases about $8 \%$ over the 270 years. If the SOM decomposition rate is increased from $0.35 \%$ to $0.375 \%$, then SOM levels are similar to those when fine root turnover was set to 2.0 year ${ }^{-1}$ and yield also returns to the previous level. The explanation is that increasing fine root turnover raises predicted tree $\mathrm{N}$ demand which reduces yield. However, the extra fine root biomass produced decays rapidly and increases the amount of SOM. Therefore the SOM decomposition rate can be raised without depleting the SOM. This increases the $\mathrm{N}$ available for tree growth due to increased mineralization from SOM decomposition.

We assumed that $10 \%$ of the original biomass of all decomposing materials would eventually enter the SOM pool, the rest being lost to the atmosphere through respiration. Changes in this assumption also alter predictions of yield. However, like changes in fine root turnover, these too can be offset by relatively small changes in the SOM decomposition rate. All of these changes are well below the threshold of our current ability to measure SOM turnover rates.

For the management simulations we set the SOM decomposition rate so that the initial SOM level was maintained for 270 years under minimum intensity management with three 90 -year rotations, no thinning, and a clearcut harvest in which only stem-wood and bark were removed. It must be emphasized, however, that this choice of SOM decomposition rate was not arbitrary. Lower values caused SOM to accumulate and yield to drop off dramatically even under very low-intensity management. Higher values caused SOM levels to fall and $\mathrm{NO}_{3}{ }^{-}$leaching to reach unreasonably high levels. That the SOM decomposition rate we chose resulted in both stable SOM levels and stable yield under low-intensity management suggests that the value may not be too far in error.

\section{MANAGEMENT SIMULATIONS}

Having defined rate parameters and initial states, we used the model to project long-term effects of four management systems on site productivity over a 540 -year period. All rotations started with a planting of 1500 seedlings per ha:

System A: low-intensity management with 90 -year rotations and clearcut harvest, no thinning, stems-only harvest.

System B: management for biomass with 45-year rotations, pre-commercial thinning at age 15 , commercial thinning at age 30 , clearcut harvest, stems-only harvest.

System C: same as B, but with whole-tree removal at harvest.

System D: 30 year rotations with whole-tree harvest.

The least intensive system, A, resulted in stable forest floor and SOM levels throughout the 540-year simulation because the SOM decomposition rate had been set to maintain a constant SOM level under this management system. The more intensive systems caused marked depletion of SOM and forest floor 

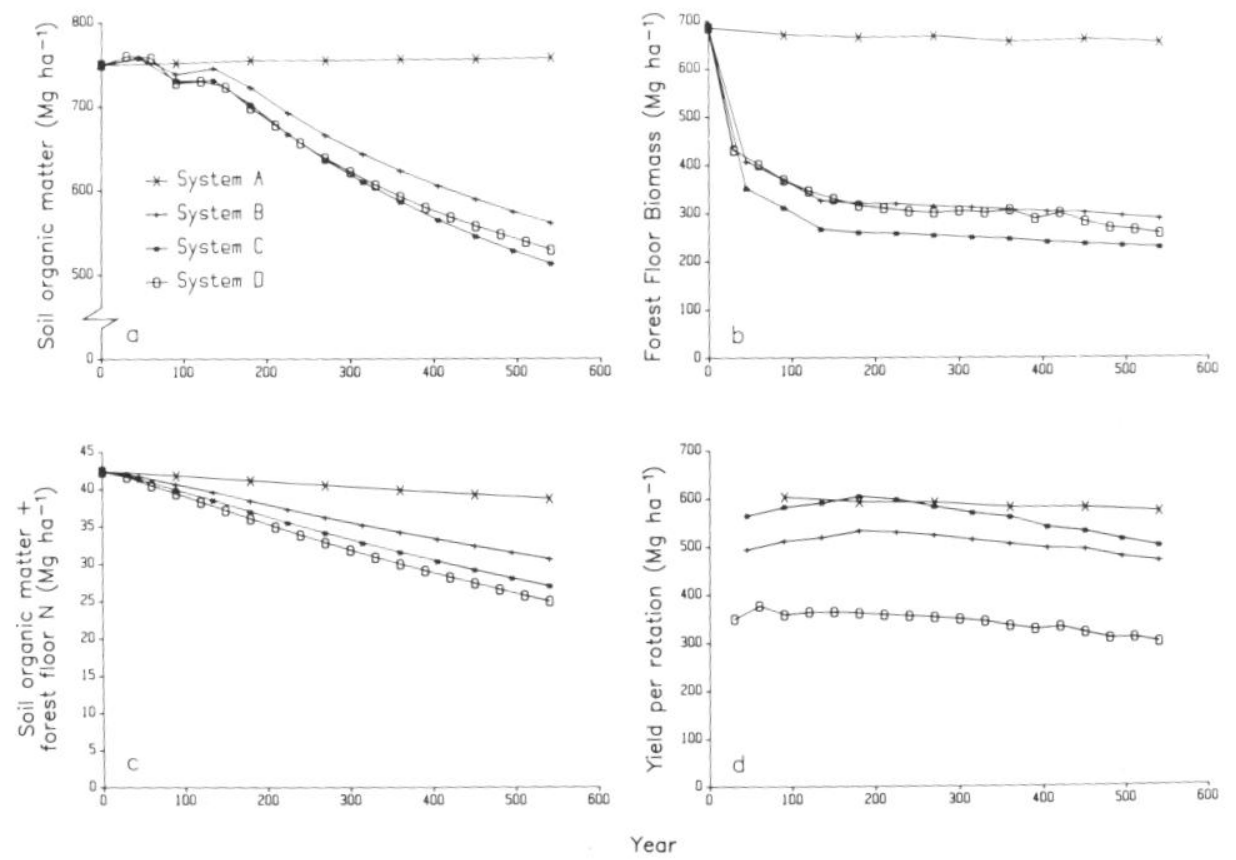

Fig. 5. Projected effect of four management systems on forest system behavior over a 540-year simulation.

System A: Low intensity management with 90-year rotations and clearcut harvest, no thinning, stems-only utilization

System B: Management for biomass with 45-year rotations, precommercial thinning at age 15, commercial thinning at age 30 , clearcut harvest, stems-only utilization

System C: Same as B but with whole-tree removal at harvest

System D: 30-year rotations with whole-tree harvest. (a) Soil organic matter. (b) Forest floor biomass. (c) Soil organic matter + forest floor N. (d) Yield per rotation.

biomass and N (Figs. 5a, b, c). Depletion of the SOM eventually decreased N mineralization, reducing the amount of $\mathrm{N}$ available for tree growth and causing eventual decline in yield (Fig. 5 d). Total stemwood yield for the 540-year simulation was maximum under system B, 45-year rotations with thinning. Biomass yield from whole-tree harvesting was greatest under 45 -year rotations, system C (Fig. 6).

The model predicted one clearly incorrect pattern; yields from commercial thinnings were consistently overestimated because the model calculated individual tree biomass as stand biomass per hectare divided by number of trees per ha. Therefore, simulated thinnings and natural mortality removed average-size trees rather than smaller, suppressed trees (J.P. Kimmins, personal communication, 1983).

Available soil $\mathrm{N}$ often increased for the first 150-200 years under the more intensive biomass utilization systems, after which it decreased, often to levels 


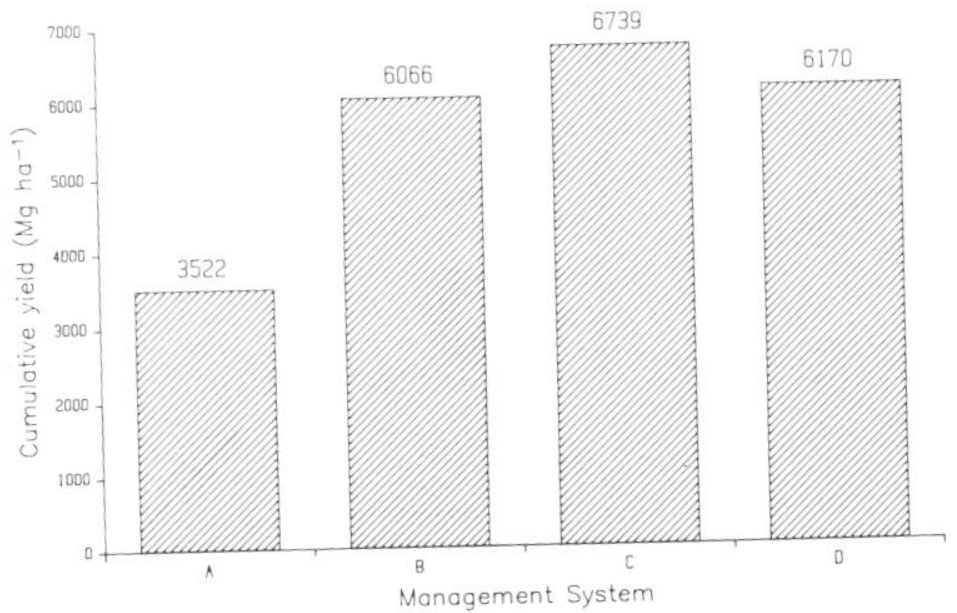

Fig. 6. Cumulative yield over a 540-year simulation under the four management systems used in Fig. 5.

below those of the first rotation. This effect in the model was caused by an interaction of two mechanisms. The initial increase in available $\mathrm{N}$ was caused by removal of tree biomass, which decreased forest floor biomass and in turn the amount of $\mathrm{N}$ immobilized annually by the forest floor microflora, leaving more $\mathrm{N}$ available for uptake by plants (cf. Vitousek and Matson, 1984). However, the increased removal of tree biomass eventually lowered the rate of transfer to SOM. As the amount of SOM decreased, the amount of N mineralized dropped, and available $\mathrm{N}$ decreased in later rotations. This is not an unreasonable result. Material enters the SOM compartment through decomposition of forest floor materials and through root death. Shorter rotations, commercial thinnings, and increased utilization remove biomass that would eventually enter the SOM via natural mortality and litterfall. The resulting decrease in SOM (Fig. 5a) did not occur in the model for about 150 years even under the most intensive management systems because decomposing tree boles from the pre-management old-growth forest continued to contribute to SOM.

The initial increase in soil available $\mathrm{N}$ caused yield to increase for the first few rotations under short-rotation management (Fig. $5 \mathrm{~d}$ ), then to drop in subsequent rotations as available soil $\mathrm{N}$ decreased. The model predicted the initial increase because we assumed that only $\mathrm{N}$ availability limited tree growth. If another factor such as phosphorus availability were to become limiting during the flush of $\mathrm{N}$ mineralization, growth might not increase. Radwan and Shumway (1983) have suggested that P may be limiting at some coastal hemlock sites. However, $\mathrm{P}$ removal by repeated harvesting should only have a minor impact on long-term $\mathrm{P}$ availability at these sites because large stores of organic and inorganic $\mathrm{P}$ are present in the mineral soil. 


\section{IMPLICATIONS FOR RESEARCH AND LONG-TERM MANAGEMENT}

Much of the uncertainty associated with the model's predictions arises from a lack of knowledge about ecosystem processes. Most importantly our ability to predict SOM decomposition and $\mathrm{N}$ mineralization rates has improved little in the last two decades (Paul and Juma, 1981). Future research should focus on SOM, and decomposition of large and medium-size roots and woody debris. Losses of $\mathrm{N}$ through denitrification also need to be quantified. In general, our experience with FORCYTE-10 suggests that SOM and soil N levels observed in coastal second growth hemlock stands will remain stable under low-intensity management. However, intensive management characterized by shorter rotations, commercial thinning and increased utilization standards are projected as depleting soil $\mathrm{N}$, causing an eventual decline in productivity. The predicted decline in yield resulting from depletion of the soil $\mathrm{N}$ by intensive management is relatively small over the 540 -year simulation period. However, predicted losses of soil and forest floor $\mathrm{N}$ were as high as $41 \%$.

Whether to believe and act upon these predictions is problematic. These highly productive coastal hemlock lands contain exceptionally large amounts of $\mathrm{N}$ in SOM that has been accumulating since before the most recent glacial advance. Therefore, the sites should be among the least sensitive to productivity loss due to SOM depletion. Nevertheless, given the inevitable uncertainty in long-term predictions, it may be more prudent to protect SOM levels by using longer rotations and less intensive harvest methods until further research and improved models can be sharpen our predictions. Certainly it appears much easier to lose SOM than to replace it.

\section{ACKNOWLEDGEMENTS}

This research was supported by grants from Crown Zellerbach Corporation, Weyerhauser, and the U.S. Forest Service Pacific Northwest Forest and Range Experiment Station (RWU-2107). The authors gratefully acknowledge the assistance provided by W. Shields and R.H. Walkup at Crown Zellerbach Forestry Research Division, and by J.P. Kimmins and K. Scoullar, FORCYTE's

developers. We thank the Canadian Forestry Service for permission to use the model. In addition, D. Perry, J. Beuter, and R. Waring provided valuable comments on the manuscript. This is Paper 1873, Forest Research Laboratory, Oregon State University, Corvallis, OR.

\section{REFERENCES}

Barnes, G.H., 1962. Yield of even-aged stands of western hemlock. U.S. Dep. Agric. Tech. Bull. $1273,52 \mathrm{pp}$. 
Edmonds, R.L., 1980. Litter decomposition and nutrient release in Douglas-fir, red alder, western hemlock, and Pacific silver fir ecosystems in western Washington. Can. J. For. Res., 10: 327-337.

Fogel, R. and Cromack, K., Jr., 1977. Effect of habitat and substrate quality on Douglas-fir litter decomposition in western Oregon. Can. J. Bot., 55: 1632-1640.

Fujimori, T., 1971. Primary productivity of a young Tsuga heterophylla stand and some speculations about biomass of forest communities on the Oregon Coast. U.S. For. Serv. Pac. Northwest For. Range Exp. Stn. Res. Pap. PNW-12.

Graham, R.L. and Cromack, K., Jr., 1982. Mass, nutrient content, and decay rate of dead boles in rain forests of Olympic National Park. Can. J. For. Res., 12: 511-521.

Grier, C.C., 1976. Biomass, productivity, and nitrogen-phosphorus cycles in hemlock-spruce stands of the central Oregon Coast. In: W.A. Atkinson and R.J. Zasoski (Editors), Western Hemlock Management Conference. Contrib. No. 34, Institute of Forest Products, Univ. Washington, Seattle, WA, pp. 71-81.

Kimmins, J.P. and Scoullar, K.A., 1979. FORCYTE: a computer simulation approach to evaluating the effect of whole-tree harvesting on the nutrient budget in northwest forests. In: S.P. Gessel, R.M. Kenady and W.A. Atkinson (Editors), Forest Fertilization Conference, Inst. For. Resour. Contrib. No. 40, Univ. Washington, Seattle, WA, pp. 266-273.

Kimmins, J.P. and Scoullar, K.A., 1981. FORCYTE-10. In: Proc. 3rd Bioenergy R\&D Seminar, Energy Project Office, National Research Council of Canada, Ottawa, Ont., pp. 55-59.

Kimmins, J.P. and Scoullar, K.A., 1982. FORCYTE-10. A user's manual for the tenth version of the FORest nutrient Cycling and Yield Trend Evaluator. Contract Report to the Canadian Forestry Service, Ottawa, Ont., 123 pp.

Paul, E.A. and Juma, N.G., 1981. Mineralization and immobilization of soil nitrogen by microorganisms. In: F.E. Clark and T. Rosswall (Editors), Terrestrial Nitrogen Cycles. Ecol. Bull. (Stockholm), 33: 179-195.

Pienaar, L.V. and Turnbull, K.J., 1973. Chapman-Richards generalization of Van Bertalanfy's growth and model for basal area growth and yield in even-aged stands. For. Sci., 19: 2-22.

Radwan, M.A. and DeBell, D.S., 1980. Site index, growth and foliar chemical composition relationships in western hemlock. For. Sci., 26: 283-290,

Radwan, M.A. and Shumway, J.S., 1983. Soil, nitrogen, sulfur, and phosphorus in relation to growth response of western hemlock to nitrogen fertilization. For. Sci., 29: 469-477.

Sachs, D., 1983. Management effects on nitrogen nutrition and long-term productivity of western hemlock stands: an exercise in simulation with FORCYTE. M.S. Thesis, Oregon State Univ., Corvallis, OR.

Santantiono, D. and Hermann, R.K., 1985. Standing crop, production, and turnover of fine roots on dry, moderate, and wet sites of mature Douglas-fir in western Oregon. Ann. Sci. For., 42 (2): 113-142.

Sollins, P., 1982. Input and decay of coarse woody debris in coniferous stands in western Oregon and Washington. Can. J. For. Res., 12: 18-28.

Vitousek, P.M. and Matson, P.A., 1984. Mechanisms of nitrogen retention in forest ecosystems: a field experiment. Science, 225: 51-52.

Vitousek, P.M., Gosz, J.R., Grier, C.C., Melillo, J.M. and Reiners, W.A., 1982. A comparative analysis of potential nitrification and nitrate mobility in forest ecosystems. Ecol. Monogr., 52: $155-177$.

Wiley, K.N., 1978. Net and gross yields for natural stands of western hemlock in the Pacific Northwest. For. Pap. 19, Weyerhaeuser Co., Centralia, WA, 124 pp. 